\title{
P13 - Vaccination against Haemophilus B as a treatment of recurrent upper respiratory tract infections
}

\author{
Chrys Tsakona
}

From 3rd Pediatric Allergy and Asthma Meeting (PAAM)

Athens, Greece. 17-19 October 2013

Haemophilus influenza b (Hib) conjugate vaccines are highly immunogenic in infants, as $>95 \%$ develop protective antibody levels after 2 or 3 doses; hence invasive Hib disease is now uncommon in vaccinated children. The precise protective level is not clearly established, although a titre of $1 \mu \mathrm{g} / \mathrm{mL}$ is considered to offer longterm protection. Hib vaccination above the age of 5 is not recommended; the majority of older even unvaccinated children seem to be immune to Hib, probably from asymptomatic infections in infancy. The vaccine though is used in any age as a functional assay of the responsiveness of the immune system to capsular polysaccharide antigens, We present 3 children with recurrent upper respiratory tract infections where the test vaccine has also acted in a therapeutic manner.

1) A 6 yr old boy was referred to us for urticaria. His mother mentioned frequent "colds" requiring antibiotics several times a year. His serum Immunoglobulins and routine investigations were normal/negative except for the functional Hib antibody levels which were suboptimal at $0.22 \mu \mathrm{g} / \mathrm{mL}$ rising to $>10 \mu \mathrm{g} / \mathrm{mL} 4$ weeks post-vaccination, when the recurrent infections stopped.

2) Another 6 yr old was referred with eczema and the mother mentioned that he had been investigated inconclusively for unexplained lethargy. He was blowing green mucus from his "constantly blocked nose"; his functional Hib antibody levels were suboptimal at $<0.15$ rising eventually to $1.7 \mu \mathrm{g} / \mathrm{mL}$ after 3 vaccinations, which stopped the subclinical sinusitis and of course the lethargy.

3) A third child was seen for nut allergy. He missed his follow-up appointments for 18 months because he was constantly having respiratory infections, which caused bronchiectasis. A sputum sample at the time of

Dudley Group of Hospitals NHS Foundation Trust, Dudley, United Kingdom the diagnosis grew Haemophilus (not typed) and started prophylactic antibiotics. A blood test a month later showed suboptimal levels of functional antibody and subsequently excellent response to the vaccination; the infections stopped, although one could argue this was an effect of the prophylactic antibiotics.

Our relevant adult and paediatric data is currently being studied and processed as this is a new therapeutic aspect.

Published: 28 February 2014

doi:10.1186/2045-7022-4-S1-P68

Cite this article as: Tsakona: P13 - Vaccination against Haemophilus B as a treatment of recurrent upper respiratory tract infections. Clinical and Translational Allergy 2014 4(Suppl 1):P68.

Submit your next manuscript to BioMed Central and take full advantage of:

- Convenient online submission

- Thorough peer review

- No space constraints or color figure charges

- Immediate publication on acceptance

- Inclusion in PubMed, CAS, Scopus and Google Scholar

- Research which is freely available for redistribution 